\title{
ANALISIS ALIRAN BEBAN PADA SISTEM TENAGA LISTRIK DI KSO PERTAMINA EP - GEO CEPU INDONESIA DISTRIK 1 KAWENGAN MENGGUNAKAN SOFTWARE ETAP 12.6
}

\author{
CAHYO KUMOLO \\ PT.PROLINDO ADITYA PRIMA \\ JL. PERAK TIMUR NO. 52 SURABAYA \\ cahyokumolo92@gmail.com
}

\begin{abstract}
Abstrak
Sistem interkoneksi merupakan salah satu dari beberapa sistem jaringan yang diterapkan pada sistem tenaga listrik pada sebuah plant khususnya di KSO Pertamina EP-Geo Cepu Indonesia Distrik I Kawengan. Seiring bertambahnya beban, maka perubahan terhadap sistem tenaga listrik tak dapat terhindarkan. Hal ini menyebabkan kondisi jaringan sistem tenaga listrik menjadi semakin kompleks dan rumit. Tanpa adanya pengelolaan yang baik terhadap jaringan sistem tenaga listrik yang kompleks dan rumit, maka akan memperbesar rugi-rugi daya yang terjadi serta memperburuk profil tegangan yang ada. Perlu adanya analisis aliran beban untuk mengetahui profil tegangan dan rugi-rugi daya, dan melakukan evaluasi untuk memperbaiki profil tegangan dan rugi-rugi daya yang ada.

Penelitian dimulai dengan pengumpulan data sistem tenaga listrik yang ada di KSO Pertamina EP-Geo Cepu Indonesia Distrik I Kawengan, setelah itu dilakukan pemodelan sistem ke dalam ETAP 12.6. Dalam memperbaiki profil tegangan dan rugi-rugi daya pada simulasi ini dibagi menjadi beberapa tahap, yaitu tahap pertama, kedua, ketiga dan keempat. Tahap pertama merupakan hasil simulasi yang belum adanya evaluasi. Tahap kedua setelah adanya evaluasi pada beberapa komponen. Simulasi tahap ketiga melakukan evaluasi lebih lanjut pada beberapa komponen. Simulasi tahap keempat adalah memastikan bahwa kondisi profil tegangan dan rugi-rugi daya sudah membaik.

Hasil simulasi yang dilakukan adalah saat beban beroperasi $100 \%$. Simulasi pertama menunjukkan banyak terjadi drop tegangan dibeberapa bus dan memiliki rugi-rugi daya yang cukup besar. Evaluasi yang pertama dilakukan yaitu pada pembangkit karena pembangkit yang berkapasitas $1450 \mathrm{KVA}$ harus memenuhi semua beban yang mencapai $2801 \mathrm{KW}$, evaluasi dilakukan dengan penggunaan 3 pembangkit yaitu 2 pembangkit 1450 KVA dan $500 \mathrm{KVA}$. Evaluasi yang lain juga dilakukan pada komponen yang mengalami overload maupun under votage. Pada simulasi pada tahap pertama terdapat losses daya aktif sebesar 331.7 KW dan losses daya reaktif sebesar 311.6 Kvar, dengan adanya evaluasi di beberapa komponen sampai tahap keempat diperoleh losses daya aktif sebesar 74.1 KW dan losses daya reaktif sebesar 144.8 Kvar.
\end{abstract}

Kata kunci : Analisis aliran beban, ETAP, Newton-Raphson

\begin{abstract}
Interconnect system is one of the few network system which is applied to the electric power system at a plant, especially in KSO Pertamina EP - Geo Cepu Indonesia District 1 Kawengan. With increasing load, the changes to the electricity system can not be avoided. This causes the electric power system network conditions become more complex and complicated. Without the proper management of the network power systems complex and complicated, it will increase the power losses that occur and worsen the existing voltage profile. The need for load flow analysis to determine the voltage profile and power losses, and conducting evaluations to improve voltage profile and power losses existing.
\end{abstract}


The study began with data collection systems existing power in KSO Pertamina EP - Geo Cepu Indonesia District 1 Kawengan, after it's done modeling system into ETAP 12.6. In fixing voltage profile and power losses in this simulation is divided into several stages, the first stage, second, third and fourth. The first stage is the result of the simulation is not an evaluation. The second phase after evaluation on multiple components. Simulation of the third stage do further evaluation on some components. Simulation fourth stage is to ensure that the condition of the voltage profile and power losses has improved.

The simulation is currently running at $100 \%$ load. The first simulation shows much going on several bus voltage drop and power loss has big enough. The first evaluation made at the plant since $1450 \mathrm{kVA}$ generating capacity must meet all load reached $2801 \mathrm{~kW}$, evaluation is performed with the use of three plants, namely two generators $1450 \mathrm{kVA}$ and $500 \mathrm{kVA}$. Another evaluation is also conducted on components that will get overloaded and under votage. In the simulation in the first stage there were losses amounting to $331.7 \mathrm{~kW}$ active power and reactive power losses amounted to $311.6 \mathrm{kVAr}$, with their evaluation in several components to the fourth stage obtained active power losses amounted to $74.1 \mathrm{~kW}$ and reactive power losses amounted to $144.8 \mathrm{kVAr}$.

Keywords: load flow analysis, ETAP, Newton-Raphson

\section{PENDAHULUAN}

Sistem interkoneksi merupakan salah satu dari beberapa sistem jaringan yang diterapkan pada sistem tenaga listrik pada sebuah plant. Seiring bertambahnya beban, maka perubahan terhadap sistem tenaga listrik tak dapat terhindarkan. Hal ini menyebabkan kondisi jaringan sistem tenaga listrik menjadi semakin kompleks dan rumit. Tanpa adanya pengelolaan yang baik terhadap jaringan sistem tenaga listrik yang kompleks dan rumit, maka akan memperbesar rugi-rugi daya yang terjadi serta memperburuk profil tegangan.

Studi aliran beban adalah penentuan atau perhitungan tegangan, arus, daya aktif, faktor daya dan daya reaktif yang terdapat pada berbagai titik dalam suatu jaringan sistem tenaga listrik pada keadaan pengoperasian normal, baik yang sedang berjalan maupun yang diharapkan akan terjadi di masa yang akan datang (William D. Stevenson, Jr., 1994:6).

Metode komputasi yang sering dipakai untuk menyelesaikan perhitungan aliran beban antara lain metode Newton Raphson, Fast Decoupled, dan Gauss Seidel. Metode Newton-Raphson secara matematis lebih baik dibandingkan dengan metode Gauss-Seidel, karena memiliki sifat kovergensi kuadratik. Untuk sistem yang besar, metode Newton-
Raphson jauh lebih efisien dan lebih praktis. Banyaknya iterasi yang diperlukan dengan metode Newton-Raphson yang menggunakan admitansi bus, praktis tidak tergantung pada banyaknya bus. Waktu yang diperlukan untuk metode Gauss-Seidel (admitansi bus) meningkat hampir sebanding dengan banyaknya bus. Sebaliknya, penghitungan matriks Jacobian pada metode NewtonRaphson akan memakan waktu yang cukup lama, sedangkan waktu yang diperlukan untuk tiap iterasi pada metode Newton-Raphson adalah lebih singkat. Waktu yang singkat untuk suatu penyelesaian dengan ketelitian yang sama, menyebabkan bahwa metode Newton-Raphson lebih banyak dipilih untuk semua sistem, seperti pada sistem distribusi (Muksin Aksin Jaelani, 2008:28).

Software ETAP Power Station 12.6 adalah sebuah software yang digunakan untuk keperluan simulasi suatu jaringan tenaga listrik. Salah satu kemampuan software ETAP adalah mensimulasikan studi aliran beban suatu jaringan listrik. Berdasarkan simulasi yang dilakukan pada software ETAP maka akan diketahui besarnya rugi-rugi daya dan kondisi profil tegangan pada sistem tenaga listrik. Salah satu manfaat dari analisis aliran beban yaitu dengan diketahuinya nilai tegangan, arus dan daya, maka dapat dilakukan 
sebuah analisis sistem tenaga listrik yang digunakan untuk meminimalkan rugi-rugi daya yang terjadi dan memperbaiki profil tegangan yang ada.

Solusi untuk memperbaiki profil tegangan dan rugi-rugi daya antara lain dengan penambahan kapasitor shunt, perbaikan ukuran kabel, penambahan bus. Perbaikan-perbaikan tersebut tentunya akan mengeluarkan biaya yang sesuai dengan kriteria kondisi profil tegangan dan rugi-rugi daya pada suatu sistem. Perbaikan kabel dan pemasangan kapasitor shunt haruslah secara hati-hati dan telah diperhitungkan dengan matang, kesalahan pemberian nilai kapasitor juga akan mempengarui sistem bahkan bisa menjadi beban, maka dari itu diperlukannya analisis aliran beban untuk mengevaluasi kondisi sistem yang ada demi keamanan dan kehandalan sistem tenaga listrik pada suatu plant.

\section{METODE}

\subsection{Rancangan Penelitian}

Penelitian tugas akhir ini penulis menggunakan metodologi penulisan sebagai berikut :

1. Pengumpulan Data

Pengumpulan data adalah berupa pengumpulan data untuk diolah dalam penelitian ini. Pada penelitian ini data yang dibutuhkan antara lain adalah keterangan aliran daya dan diagram single line pada sistem tenaga listrik di KSO Pertamina EP - Geo Cepu Indonesia Distrik I Kawengan.

2. Analisis Data

Analisis data adalah sebuah proses untuk memahami data yang diperoleh dari proses pengumpulan data, dimana pada proses ini dapat diketahui bahwa sebuah sistem masih dapat bekerja dengan baik atau tidak.

3. Perancangan Sistem

Perancangan sistem adalah proses dimana hasil dari analisis data pertama jika ada hasil yang tidak sesuai dengan standart IEC untuk dilakukan perbaikan demi keamanan dan kehandalan sistem.

4. Pengujian dan Analisa data

Pengujian dan analisa data adalah tahap akhir pengujian rancangan setelah perbaikan serta membandingkan dengan hasil lapangan kemudian menarik kesimpulan.

2.2 Gambaran Sistem Tenaga Listrik

Penelitian yang dilakukan ini mengambil data sistem tenaga listrik di KSO Pertamina EP - Geo Cepu Indonesia Distrik 1 Kawengan. Gambar singleline diagram di ETAP Power Station 12.6 dapat dilihat gambar 1 . 


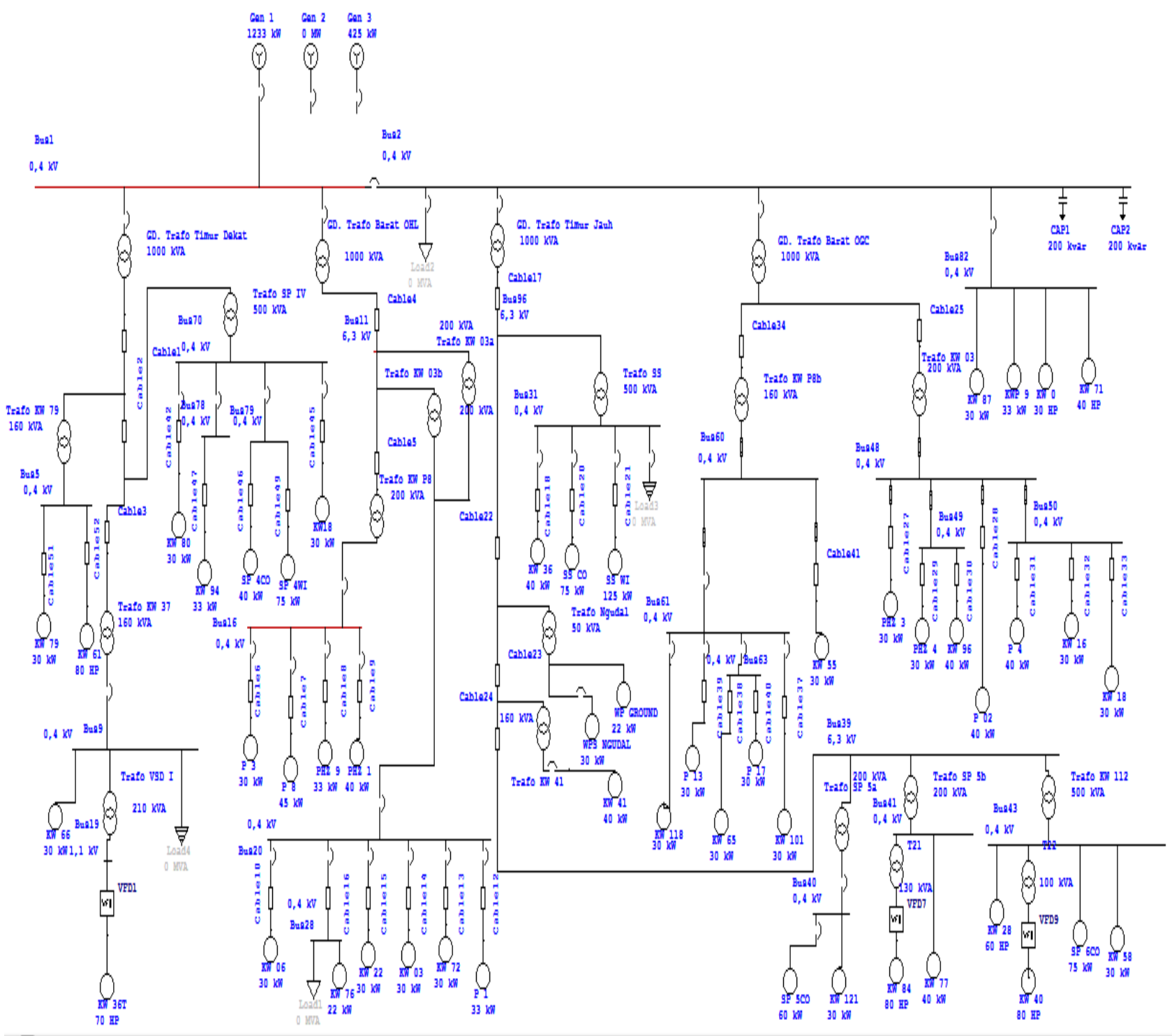

Gambar 1. Single line diagram

\section{HASIL DAN PEMBAHASAN}

3.1 Simulasi Aliran Beban Tahap Pertama

Simulasi aliran beban tahap pertama dilakukan pada model jaringan sistem tenaga listrik Pertamina EP - Geo Cepu Indonesia Distrik I Kawengan sesuai dengan data masukan daftar beban dan single line diagram yang ada. Simulasi tahap pertama bertujuan untuk mengetahui kondisi rugi-rugi daya dan profil tegangan sebelum ada penambahan kapasitor. Gambar 2 merupakan gambar hasil simulasi aliran beban dengan menggunakan software ETAP 12.6. Dari Gambar 2 dapat diketahui bahwa ada beberapa komponen yang berwarna ungu dan merah. Komponen yang berwarna Ungu berarti dalam kondisi marginal dan yang berwarna merah berarti dalam kondisi critical. Dalam hal ini kondisi marginal masih dalam kondisi toleransi dan masih dalam kondisi aman, namun untuk komponen yang berwarna merah perlu adanya evaluasi untuk tindak lanjut demi kehandalan dan keamanan pada sebuah sistem tenaga listrik.

Gambar 2 menunjukkan bahwa banyak terjadi drop tegangan pada Gardu Trafo Timur Jauh dan komponen dibawahnya, bahkan pada bus paling ujung dari GD. Trafo Timur Jauh tegangannya hanya mencapai $82.86 \%$. Hal yang sama terjadi juga pada pada jaringan GD. Trafo Barat OGC, jaringan dibawahnya 
memiliki level tegangan mencapai $91.52 \%$. Selain itu, kondisi pada tiap percabangan, ada beberapa kabel yang mengalami over load. Kabel dalam kondisi over load ditandai dengan warna merah. Kurang besarnya ukuran kabel akan membuat drop tegangan pada branch berikutnya. Selain itu ketika kabel mengalami overload akan mengakibatkan panas berlebih pada kabel, lebih parah lagi dapat mengakibatkan kebakaran jika ada beberapa proteksi yang tidak bekerja. Terdapat juga beberapa Trafo yang mengalami over load, over load ini juga dapat diakibatkan karena adanya drop tegangan. Jadi langkah sebelum mengubah kapasitas trafo adalah meperbaiki profil tegangan yang ada.

Tabel 1. load flow report menunjukkan dari bus utama yaitu bus yang menerima tegangan langsung dari pembangkit. Pada bus tersebut memberi daya aktif sebesar $2821 \mathrm{~kW}$ dan daya reaktif sebesar $1048 \mathrm{kVAr}$ sedangakan kapasitas pembangkit sebesar $1450 \mathrm{kVA}$ atau $1233 \mathrm{~kW}$. Pembangkit akan tidak mampu jika pada sistem beban beroperasi $100 \%$. Simulasi ini dilakukan dengan semua pengoperasian beban sebesar $100 \%$, maka dari itu perlu adanya evaluasi untuk mengurangi rugi-rugi daya dan profil tegangan agar sistem memiliki tingkat keamanan dan kehandalan yang baik.

Tabel 2. menunjukkan rugi - rugi daya pada tiap komponen. Pada simulasi tahap pertama ini dengan kapasitas dari generator yang kurang terjadi losses daya aktif sebesar $331.7 \mathrm{~kW}$ sedangakan total daya reaktifnya adalah 311.6 kVAr. Rugi-rugi daya tersebut tentu akan sangat membebani pembangkit.

Tabel 3. menunjukkan beberapa bus yang mengalami drop tegangan dibawah toleransi yang diijinkan yaitu sebesar 5\%. Solusi untuk mengurangi drop tegangan pada bus antara lain adalah pemberian kapasitor, memperbesar luas penampang, penambahan bus dan lainlain. Pemberian kapasitor juga harus sesuai dengan nilai daya reaktif yang dibutuhkan karena jika kapasitor yang diberikan ukurannya terlalu kecil maka akan hanya membantu daya reaktif yang kecil, sedangkan kapasitor yang diberikan terlalu besar maka akan menjadi beban. 


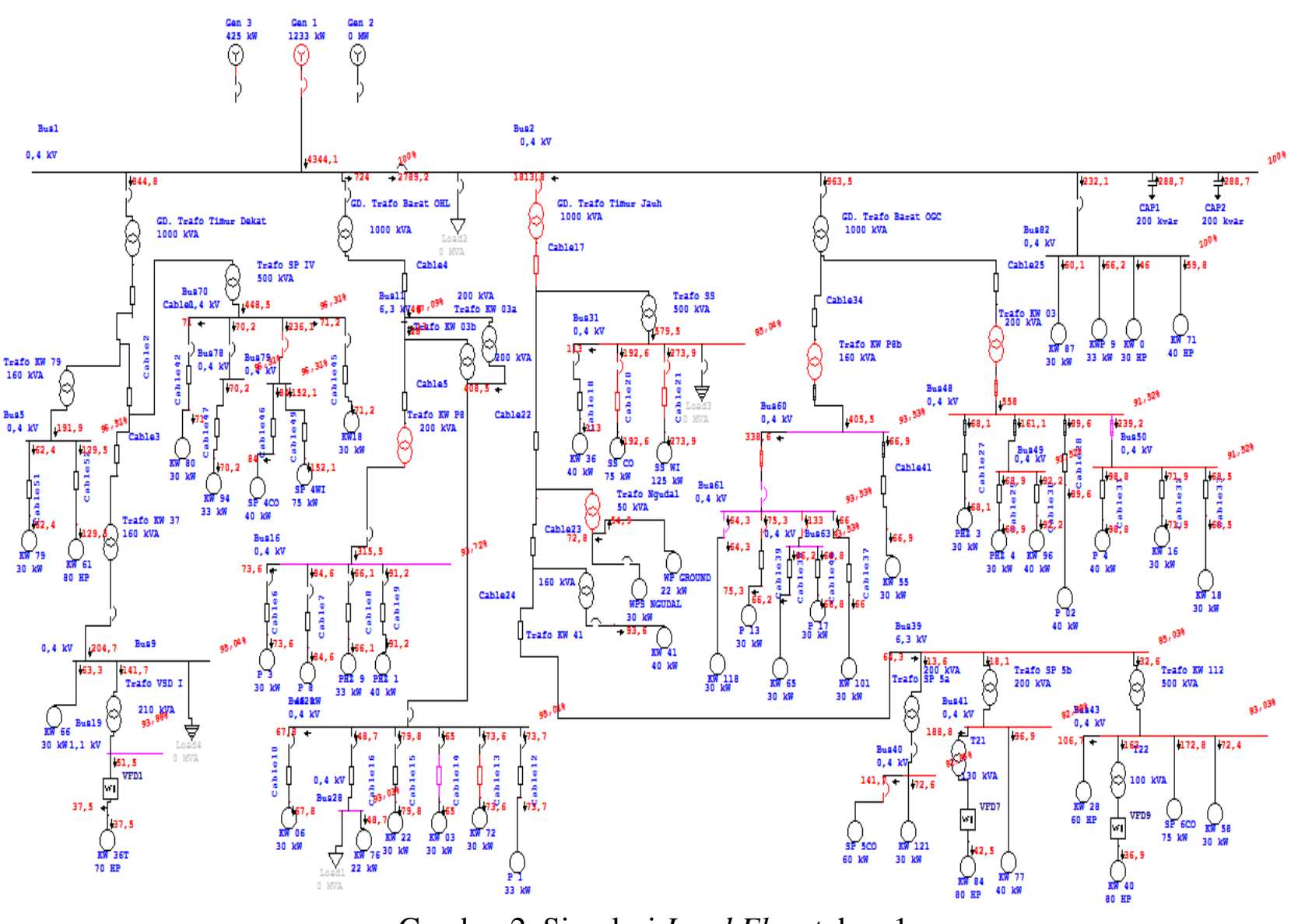

Gambar 2. Simulasi Load Flow tahap 1 
Tabel 1. Tabel Load Flow Report Tahap 1

\section{LOAD FLOW RE PORT}

\begin{tabular}{|c|c|c|c|c|c|c|c|c|c|c|c|c|c|c|}
\hline \multicolumn{3}{|c|}{ Bus } & \multicolumn{2}{|c|}{ Voltage } & \multicolumn{2}{|c|}{ Generation } & \multicolumn{2}{|c|}{ Load } & \multicolumn{5}{|c|}{ Load Flow } & \multirow{2}{*}{$\begin{array}{c}\text { XFMR } \\
\text { \%T:p }\end{array}$} \\
\hline & ID & $\mathrm{sv}$ & $\% \mathrm{Maz}$ & Ang. & $\mathrm{Mw}$ & Mves & $\mathrm{MW}$ & Mver & & $\mathrm{MW}$ & Mver & Amp & $\% \mathrm{PF}$ & \\
\hline \multirow[t]{3}{*}{ • Bvsl } & & 0.400 & 100.000 & 0.0 & 2.821 & 1.048 & 0 & 0 & Bves & 0.530 & 0.248 & 844.8 & 90.6 & \\
\hline & & & & & & & & & Bvs10 & 0.443 & 0.235 & 724.0 & 88.4 & \\
\hline & & & & & & & & & $B=12$ & 1.848 & 0.565 & 2789.2 & 95.6 & \\
\hline \multirow[t]{4}{*}{ Bes2 } & & 0.400 & 100.000 & 0.0 & 0 & 0 & 0.000 & -0.400 & $B=129$ & 1.119 & 0.571 & 1813.8 & 89.1 & \\
\hline & & & & & & & & & Bvst 6 & 0.584 & 0.323 & 963.5 & 87.9 & \\
\hline & & & & & & & & & Bvsl & -1.848 & -0.565 & 2789.2 & 95.6 & \\
\hline & & & & & & & & & Buss2 & 0.144 & 0.071 & 232.1 & 89.8 & \\
\hline \multirow[t]{2}{*}{ Bves } & & 6.300 & 98.708 & .0 .2 & 0 & 0 & 0 & 0 & Best & 0.524 & 0.243 & 53.6 & 90.7 & \\
\hline & & & & & & & & & Bvsl & .0 .524 & -0.243 & 53.6 & 90.7 & \\
\hline \multirow[t]{3}{*}{ Bost } & & 6.300 & 98.340 & .0 .2 & 0 & 0 & 0 & 0 & Bves & -0.522 & -0.242 & 53.6 & 90.7 & \\
\hline & & & & & & & & & Bss6 & 0.403 & 0.188 & 415 & 90.6 & \\
\hline & & & & & & & & & Bess & 0.119 & 0.054 & 122 & 910 & \\
\hline \multirow[t]{3}{*}{ Bess } & & 0.400 & 96513 & .0 .5 & 0 & 0 & 0 & 0 & Bves:3 & 0.037 & 0.018 & 624 & 89.9 & \\
\hline & & & & & & & & & Bvs84 & 0.080 & 0.034 & 129.5 & 919 & \\
\hline & & & & & & & & & Bvost & -0.117 & -0.053 & 1919 & 912 & \\
\hline \multirow[t]{3}{*}{ Bss6 } & & 6.300 & 98.120 & .0 .2 & 0 & 0 & 0 & 0 & Bost & -0.402 & -0.188 & 41.5 & 90.6 & \\
\hline & & & & & & & & & Boss & 0.128 & 0.054 & 13.0 & 922 & \\
\hline & & & & & & & & & Bes70 & 0.274 & 0.134 & 28.5 & 89.9 & \\
\hline \multirow[t]{2}{*}{ Boss } & & 6.300 & 97982 & .0 .2 & 0 & 0 & 0 & 0 & Bss6 & -0.128 & -0.054 & 130 & 922 & \\
\hline & & & & & & & & & Bvsg & 0.128 & 0.054 & 13.0 & 922 & \\
\hline \multirow[t]{2}{*}{$B=29$} & & 0.400 & 95.045 & -1.4 & 0 & 0 & 0.037 & 0.018 & Bvos & -0.125 & -0.050 & 204.7 & 929 & \\
\hline & & & & & & & & & Bvs19 & 0.088 & 0.031 & 141.7 & 94.1 & \\
\hline \multirow[t]{2}{*}{ Bvas 10} & & 6.300 & 98.262 & -1.3 & 0 & 0 & 0 & 0 & Bvsll & 0.441 & 0.221 & 460 & 89.4 & \\
\hline & & & & & & & & & Bvsl & -0.441 & -0.221 & 46.0 & 89.4 & \\
\hline \multirow[t]{4}{*}{ Bvsll } & & 6.300 & 97.091 & -1.1 & 0 & 0 & 0 & 0 & Bvs10 & -0.435 & -0.219 & 46.0 & 89.3 & \\
\hline & & & & & & & & & Bvals & 0.199 & 0.096 & 200 & 89.1 & \\
\hline & & & & & & & & & Bvs14 & 0.123 & 0.061 & 13.0 & 39.4 & \\
\hline & & & & & & & & & Bvs14 & 0.123 & 0.061 & 130 & 39.4 & \\
\hline \multirow[t]{3}{*}{ Bvos14 } & & 0.400 & 95010 & -2.7 & 0 & 0 & 0 & 0 & Bvsll & -0.122 & -0.057 & 2043 & 90.6 & \\
\hline & & & & & & & & & Bvsll & -0.122 & -0.057 & 2043 & 90.6 & \\
\hline & & & & & & & & & Bvs20 & 0.244 & 0.114 & 408.5 & 90.6 & \\
\hline \multirow[t]{2}{*}{ Busls } & & 6.300 & 96938 & -1.1 & 0 & 0 & 0 & 0 & Bvsll & -0.199 & -0.096 & 200 & 89.0 & \\
\hline & & & & & & & & & Bvs16 & 0.189 & 0.096 & 200 & 89.0 & \\
\hline \multirow[t]{3}{*}{ Bss16 } & & 0.400 & 93.719 & -3.6 & 0 & 0 & 0 & 0 & Bvs1? & 0.044 & 0.020 & 73.6 & 910 & \\
\hline & & & & & & & & & Bve227 & 0.050 & 0.023 & $\$ 4.6$ & 910 & \\
\hline & & & & & & & & & Bv 216 & 0.039 & 0.018 & 66.1 & 90.6 & \\
\hline
\end{tabular}


Tabel 2. Total Losses pada saat pengujian pertama

\begin{tabular}{|c|c|c|c|c|c|c|c|c|c|}
\hline \multirow{2}{*}{$\frac{\text { CKT / Branch }}{\text { ID }}$} & \multicolumn{2}{|c|}{ From-To Bus Flow } & \multicolumn{2}{|c|}{ To-From Bus Flow } & \multicolumn{2}{|c|}{ Losses } & \multicolumn{2}{|c|}{$\%$ Bas Voltago } & \multirow{2}{*}{$\begin{array}{c}\text { Vd } \\
\% \text { Drop } \\
\text { in Vmag }\end{array}$} \\
\hline & $M w$ & Mvar & $M w$ & Mver & $\mathrm{Ew}$ & f var & From & To & \\
\hline GD. Trafo Barat OHL & 0.443 & 0.235 & -0.441 & -0.221 & 2.5 & 14.3 & 100.0 & 98.3 & 1.74 \\
\hline GD. Trafo Timur Dokat & 0.530 & 0.248 & .0 .524 & -0.243 & 59 & 5.2 & 100.0 & 98.7 & 1.29 \\
\hline GD. Trafo Barat OGC & 0.584 & 0.323 & .0 .577 & -0.316 & 7.7 & 6.8 & 100.0 & 98.5 & 1.50 \\
\hline GD. Trafo Timrer Jauh & 1.119 & 0.571 & -1.104 & -0.482 & 15.5 & 39.5 & 100.0 & 95.8 & 4.16 \\
\hline Cablol 1 & 0.524 & 0.243 & -0.522 & .0 .242 & 2.0 & 0.7 & 98.7 & 98.3 & 0.37 \\
\hline Cablo 2 & 0.403 & 0.198 & -0.402 & -0.138 & 0.9 & 0.3 & 98.3 & 98.1 & 0.22 \\
\hline Trafo KW 79 & 0.119 & 0.054 & -0.117 & -0.053 & 1.9 & 1.7 & 98.3 & 96.5 & 1.83 \\
\hline Cablos 1 & 0.037 & 0.018 & -0.037 & -0.018 & 0.0 & 0.0 & 965 & 96.4 & 0.09 \\
\hline Cablos 52 & 0.090 & 0.034 & .0 .074 & -0.033 & 5.5 & 1.6 & 96.5 & 90.2 & 6.31 \\
\hline Cablo 3 & 0.128 & 0.054 & -0.128 & -0.054 & 0.2 & 0.1 & 98.1 & 98.0 & 0.14 \\
\hline Trafo S P IV & 0.274 & 0.134 & .0 .272 & -0.125 & 1.9 & 9.1 & 98.1 & 963 & 1.81 \\
\hline Trafo $\mathrm{KW} 37$ & 0.128 & 0.054 & -0.125 & -0.050 & 2.8 & 4.2 & 93.0 & 95.0 & 2.94 \\
\hline Trafo VSD I & 0.088 & 0.031 & -0.087 & -0.029 & 0.5 & 2.2 & 95.0 & 939 & 1.16 \\
\hline Cablo 4 & 0.441 & 0.221 & -0.435 & .0 .219 & 6.0 & 1.2 & 98.3 & 97.1 & 1.17 \\
\hline Cablos & 0.159 & 0.096 & -0.139 & -0.096 & 0.3 & 0.1 & 97.1 & 969 & 0.15 \\
\hline Trafo KW 03a & 0.123 & 0.061 & -0.122 & -0.057 & 1.0 & 4.7 & 97.1 & 95.0 & 2.08 \\
\hline Trafo KW 03b & 0.123 & 0.061 & -0.122 & -0.057 & 1.0 & 4.7 & 97.1 & 950 & 2.08 \\
\hline Trafo KW Ps & 0.189 & 0.096 & -0.196 & -0.085 & 2.4 & 11.2 & 969 & 93.7 & 3.22 \\
\hline Cable 6 & 0.044 & 0.020 & -0.037 & -0.018 & 6.1 & 1.5 & 93.7 & 81.7 & 1205 \\
\hline Cablo? & 0.050 & 0.023 & -0.049 & -0.023 & 0.9 & 0.2 & 93.7 & 92.1 & 1.57 \\
\hline Cablo 8 & 0.039 & 0.018 & -0.036 & -0.018 & 2.4 & 0.6 & 93.7 & 88.3 & 5.40 \\
\hline Cablog & 0.054 & 0.024 & -0.050 & -0.023 & 3.9 & 1.0 & 93.7 & 87.5 & 6.22 \\
\hline Cablo 10 & 0.040 & 0.019 & -0.037 & -0.018 & 3.0 & 0.6 & 95.0 & 88.7 & 6.26 \\
\hline Cable 12 & 0.043 & 0.022 & .0 .042 & -0.021 & 1.8 & 0.3 & 95.0 & 912 & 3.77 \\
\hline Cablo 13 & 0.045 & 0.019 & -0.037 & -0.018 & 7.1 & 0.9 & 950 & 81.7 & 13.34 \\
\hline Cablo 14 & 0.039 & 0.018 & -0.037 & -0.018 & 1.2 & 0.2 & 95.0 & 925 & 2.54 \\
\hline Cablols & 0.048 & 0.021 & -0.037 & -0.018 & 10.7 & 2.7 & 950 & 75.4 & 19.60 \\
\hline Cablo 16 & 0.029 & 0.014 & -0.028 & -0.014 & 0.7 & 0.2 & 950 & 93.0 & 1.98 \\
\hline Cablo 17 & 1.104 & 0.452 & .0 .993 & -0.467 & 1109 & 149 & 95.8 & 87.3 & 8.53 \\
\hline Cablo22 & 0.676 & 0.318 & -0.668 & -0.316 & 7.2 & 1.3 & 87.3 & 865 & 0.83 \\
\hline Trafo \& \$ & 0.317 & 0.149 & -0.314 & -0.134 & 3.2 & 15.1 & 87.3 & 85.0 & 2.28 \\
\hline Cablo 18 & 0.061 & 0.026 & .0 .050 & -0.023 & 11.3 & 2.6 & 85.0 & 70.6 & 14.47 \\
\hline Cablo20 & 0.105 & 0.044 & -0.091 & -0.040 & 13.8 & 3.5 & 85.0 & 74.5 & 1057 \\
\hline Cablo21 & 0.148 & 0.064 & -0.147 & -0.064 & 1.1 & 0.3 & 85.0 & 34.5 & 0.58 \\
\hline Cable 23 & 0.601 & 0.250 & -0.600 & -0.250 & 1.3 & 0.2 & 86.5 & 86.3 & 0.17 \\
\hline
\end{tabular}


Tabel 3. Bus Drop pada tahap pengujian pertama

\begin{tabular}{|c|c|c|c|c|}
\hline Bus ID & $\begin{array}{c}\text { Nominal } \\
\mathrm{kV}\end{array}$ & Voltage & $\begin{array}{c}\text { MW } \\
\text { Loading }\end{array}$ & \% Loading \\
\hline Bus1 & 0,4 & 100 & 2,821 & 0 \\
\hline Bus2 & 0,4 & 100 & 1,848 & 0 \\
\hline Bus5 & 0,4 & 96,51 & 0,117 & 0 \\
\hline Bus9 & 0,4 & 95,04 & 0,125 & 0 \\
\hline Bus11 & 6,3 & 97,09 & 0,435 & 0 \\
\hline Bus16 & 0,4 & 93,72 & 0,186 & 0 \\
\hline Bus19 & 1,1 & 93,88 & 0,087 & 0 \\
\hline Bus20 & 0,4 & 95,01 & 0,244 & 0 \\
\hline Bus28 & 0,4 & 93,03 & 0,028 & 0 \\
\hline Bus31 & 0,4 & 85,04 & 0,314 & 0 \\
\hline Bus39 & 6,3 & 85,03 & 0,54 & 0 \\
\hline Bus40 & 0,4 & 82,86 & 0,112 & 0 \\
\hline Bus41 & 0,4 & 82,28 & 0,151 & 0 \\
\hline Bus43 & 0,4 & 83,03 & 0,272 & 0 \\
\hline Bus48 & 0,4 & 91,52 & 0,321 & 0 \\
\hline Bus49 & 0,4 & 91,52 & 0,093 & 0 \\
\hline Bus50 & 0,4 & 91,52 & 0,138 & 0 \\
\hline Bus60 & 0,4 & 93,53 & 0,238 & 0 \\
\hline Bus61 & 0,4 & 93,53 & 0,198 & 0 \\
\hline Bus63 & 0,4 & 93,53 & 0,078 & 0 \\
\hline Bus70 & 0,4 & 96,31 & 0,272 & 0 \\
\hline Bus78 & 0,4 & 96,31 & 0,042 & 0 \\
\hline Bus79 & 0,4 & 96,31 & 0,144 & 0 \\
\hline Bus82 & 0,4 & 100 & 0,144 & 0 \\
\hline Bus96 & 6,3 & 87,31 & 0,993 & 0 \\
\hline
\end{tabular}

\subsection{Simulasi Aliran Beban Tahap Kedua}

Simulasi tahap kedua ini adalah mengevaluasi dari beberapa komponen yang bertanda merah yang artinya pada komponen tersebut ada over load maupun drop tegangan dari simulasi tahap 1. Adapun beberapa evaluasi yang dilakukan antara lain :

1. Evaluasi yang pertama dilakukan adalah pada kapasitas pembangkit. Dari simulasi tahap 1 sudah terlihat bahwa daya aktif yang dibutuhkan sistem ketika beban $100 \%$ adalah sekitar $2821 \mathrm{~kW}$, sedangkan kapasitas 1 pembangkit $1233 \mathrm{~kW}$ maka perlu penambahan pembangkit yang ada yaitu 1 pembangkit $1233 \mathrm{~kW}$ dan $425 \mathrm{~kW}$ untuk memikul semua beban yang ada pada sistem.

2. Pada bus 19 terjadi under voltage, terjadi tepat setelah trafo step up dengan tegangan 1100 volt, terlihat daya reaktif yang diserap oleh motor adalah $29 \mathrm{kVAr}$, maka perlu adanya pemasangan kapasitor bank sebesar $30 \mathrm{kVAr}$ pada bus 19 .

3. Komponen CB 55 akan trip karena arus yang ditanggung oleh $\mathrm{CB}$ sebesar 235.9 $A$, maka perlu adanya penggantian $\mathrm{CB}$ berkapasitas $250 \mathrm{~A}$.

4. Cable 17 terlihat over load karena menanggung arus sebesar 108 A dengan tegangan 1.1 KV. Penggantian kabel menjadi $35 \mathrm{~mm}^{2}$ belum cukup karena masih banyak drop tegangan pada bus paling ujung, maka perlu evaluasi kabel menjadi $50 \mathrm{~mm}^{2}$.

5. Pada bus 16 terjadi under voltage sebesar $93.72 \%$, pada bus tersebut mengalirkan daya reaktif sebesar $86 \mathrm{kVAr}$ maka perlu diberikan kapasitor bank sebesar $85 \mathrm{kVAr}$, profil tegangan menjadi naik menjadi $96.26 \%$, Trafo yang menghubungkan bus 16 yang semula over load setelah adanya pemberian kapasitor ini menjadi dalam kondisi aman. 
6. Pada bus 28 terjadi drop tegangan, mengalirkan daya reaktif sebesar 14 $\mathrm{kVAr}$, pemberian kapasitor $15 \mathrm{kVAr}$ masih belum memenuhi kenaikan tegangan agar drop tegangan yang terjadi masih diambang toleransi maka pemberian kapasitor diberikan pada bus diatasnya yaitu bus 20, pada bus 20 mengalirkan daya reaktif sebesar 113 kVAr, kapasitor bank yang diberikan adalah sebesar 115 kVAr. Pemberian kapasitor di bus 20 ini sudah dapat memperbaiki drop tegangan pada bus 28 .

7. GD. Trafo Timur Jauh terlihat over load, kVA yang disupply adalah sebesar 1067, maka perlu evaluasi trafo menjadi 1200 $\mathrm{kVA}$.

8. Trafo Ngudal juga mengalami over load, kVA yang di supply sebesar $73 \mathrm{kVA}$, maka perlu evaluasi trafo sebesar 100 kVA.

9. CB 39 juga akan trip karena arus yang dihantarkan sebesar 159 A sedangkan rating $\mathrm{CB} 80 \mathrm{~A}$, evaluasi yang diberikan adala $200 \mathrm{~A}$.

10. Trafo KW P8 juga mengalami over load, kapasitas trafo yang hanya $150 \mathrm{kVA}$ harus mengalirkan daya sebesar $236 \mathrm{kVA}$, maka perlu evaluasi trafo menjadi $250 \mathrm{kVA}$.

11. Fuse 11 akan putus karena mengalirkan arus sebesar 324 A sedangkan rating Fuse 200A, maka perlu evaluasi fuse menjadi $400 \mathrm{~A}$.

12. CB 48 akan trip karena arus yang dialirkan sebesar 71 A sedngkan rating CB sebesar 65 A, maka evaluasi CB yang diberikan adalah $80 \mathrm{~A}$
13. Pada bus 40, 41, 43 terjadi drop tegangan lebih dari $10 \%$ maka perlu diberikan kapasitor bank, daya reaktif yang mengalir pada bus 40 adalah 51 Kvar maka perlu pemasangan kapasitor bank sebesar 51 kVAr. Pada bus 41 daya reaktif yang mengalir adalah sebesar $60 \mathrm{kVAr}$, maka perlu kapasitor bank sebesar $60 \mathrm{kVAr}$ dan pada bus 43 mengalir daya reaktif sebesar 113 maka perlu penambahan kapasitor bank sebesar $115 \mathrm{kVAr}$.

14. Trafo KW 03 terlihat over load, daya yang dihantarkan adalah sebesar 318 kVA sedangkan kapasitas trafo sebesar 200 $\mathrm{kVA}$ maka perlu evaluasi trafo sebesar $400 \mathrm{kVA}$.

Tabel 4. menunjukkan bahwa ketiga pembangkit tersebut sudah mampu untuk menopang semua beban yang ada pada sistem, meskipun pada hasil simulasi terlihat ungu yag artinya dalam kondisi marginal. Hali ini dilakukan karena disesuaikan dengan pembangkit yang dimiliki.

Tabel 5. menunjukkan bahwa losses yang ada pada sistem sudah menurun yang semula losses daya aktif $331.7 \mathrm{~kW}$ dan losses daya reaktif $311.6 \mathrm{kVAr}$ sekarang sudah turun yaitu untuk losses daya aktif sebesar $211.3 \mathrm{~kW}$ dan losses daya reaktif sebesar $202.9 \mathrm{kVAr}$.

Tabel 6. menunjukkan masih ada beberapa bus yang mengalami drop tegangan, meskipan pada bus tersebut sudah diberi kapasitor bank sesuai dengan nilai daya reaktif yang ada pada bus tersebut, perlu adanya evaluasi lebuh lanjut untuk menangani bus yang terjadi drop tegangan tersebut. 


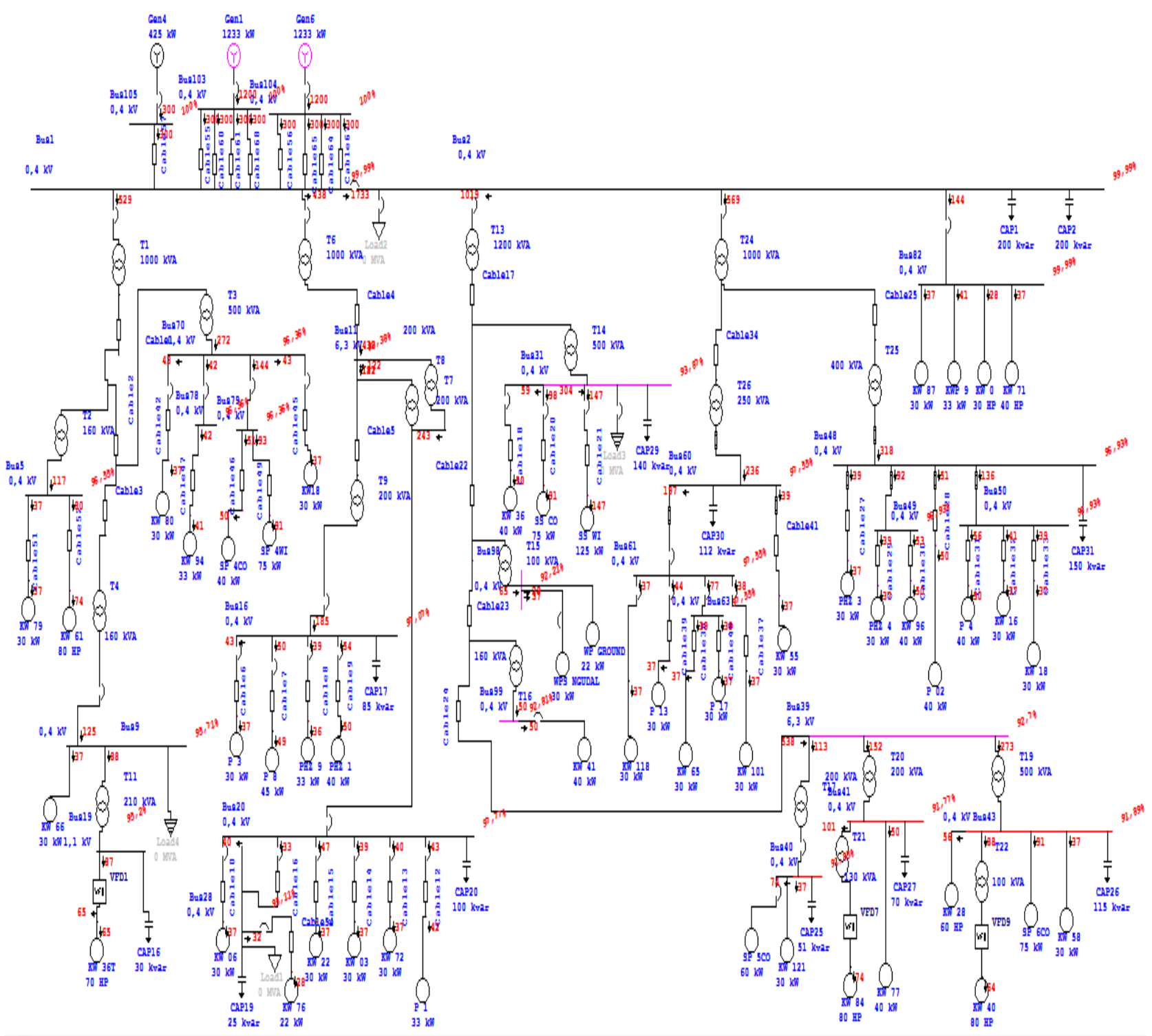

Gambar 3. Simulasi Load Flow tahap 2 
Tabel 4. Tabel Load Flow Report tahap 2

\section{LOAD FLOW RE PORT}

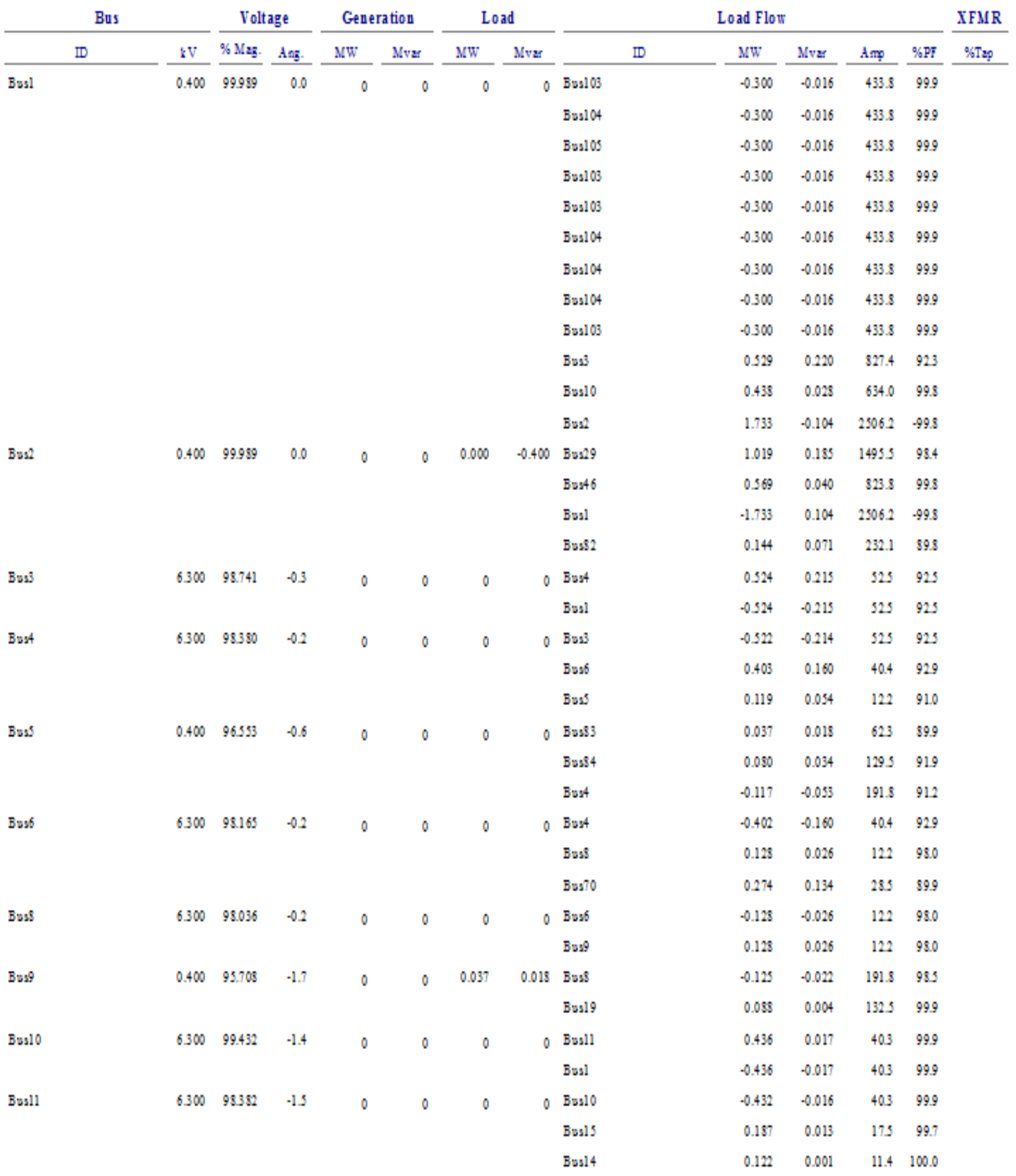


Tabel 5. Total Losses pada pengujian tahap kedua

\begin{tabular}{|c|c|c|c|c|c|c|c|c|c|}
\hline \multirow{2}{*}{$\frac{\text { CKT / Branch }}{\text { ID }}$} & \multicolumn{2}{|c|}{ From-To Bus Flow } & \multicolumn{2}{|c|}{ To-From Bus Flow } & \multicolumn{2}{|c|}{ Losses } & \multicolumn{2}{|c|}{$\%$ Bus Voltago } & \multirow{2}{*}{$\begin{array}{c}\text { Vd } \\
\% \text { Drop } \\
\text { in Vrag }\end{array}$} \\
\hline & Mw & Mvar & Mw & Mvar & $\mathrm{bw}$ & iver & From & To & \\
\hline Cabloss & -0.300 & -0.016 & 0.300 & 0.016 & 0.0 & 0.0 & 100.0 & 100.0 & 0.01 \\
\hline Cablo5 6 & -0.300 & -0.016 & 0.300 & 0.016 & 0.0 & 0.0 & 100.0 & 100.0 & 0.01 \\
\hline Cablo5? & .0 .300 & -0.016 & 0.300 & 0.016 & 0.0 & 0.0 & 100.0 & 100.0 & 0.01 \\
\hline Cablo 60 & -0.300 & .0 .016 & 0.300 & 0.016 & 0.0 & 0.0 & 100.0 & 100.0 & 0.01 \\
\hline Cablo 61 & -0.300 & -0.016 & 0.300 & 0.016 & 0.0 & 0.0 & 100.0 & 100.0 & 0.01 \\
\hline Cablo 64 & -0.300 & .0 .016 & 0.300 & 0.016 & 0.0 & 0.0 & 100.0 & 100.0 & 0.01 \\
\hline Cablo 65 & .0 .300 & -0.016 & 0.300 & 0.016 & 0.0 & 0.0 & 100.0 & 100.0 & 0.01 \\
\hline Cabla 67 & -0.300 & -0.016 & 0.300 & 0.016 & 0.0 & 0.0 & 100.0 & 100.0 & 0.01 \\
\hline Cablo 68 & -0.300 & -0.016 & 0.300 & 0.016 & 0.0 & 0.0 & 100.0 & 100.0 & 0.01 \\
\hline GD. Trafo Baral OHL & 0.438 & 0.028 & -0.436 & -0.017 & 1.9 & 109 & 100.0 & 99.4 & 0.56 \\
\hline GD. Trafo Timrar Dokz: & 0.529 & 0.220 & .0 .524 & -0.215 & 5.7 & 5.0 & 100.0 & 98.7 & 1.25 \\
\hline GD. Tafo Timvs I woh & 1.019 & 0.185 & -1.011 & -0.134 & 8.8 & 50.7 & 1000 & 98.4 & 1.59 \\
\hline GD. Trafo Barzt OGC & 0.569 & 0.040 & .0 .564 & -0.035 & 5.6 & 5.0 & 100.0 & 989 & 1.04 \\
\hline Cablol & 0.524 & 0.215 & .0 .522 & .0 .214 & 2.0 & 0.7 & 98.7 & 98.4 & 0.36 \\
\hline Cablo2 & 0.403 & 0.160 & -0.402 & -0.160 & 0.9 & 0.3 & 98.4 & 982 & 0.21 \\
\hline Trafo KW 79 & 0.119 & 0.054 & -0.117 & -0.053 & 19 & 1.7 & 98.4 & 96.6 & 1.83 \\
\hline Cablos 1 & 0.037 & 0.018 & -0.037 & -0.018 & 0.0 & 0.0 & 96.6 & 965 & 0.09 \\
\hline Cablo52 & 0.090 & 0.034 & -0.074 & -0.033 & 5.5 & 1.6 & 96.6 & 903 & 6.30 \\
\hline Cabla 3 & 0.128 & 0.026 & -0.128 & .0 .026 & 0.2 & 0.1 & 98.2 & 980 & 0.13 \\
\hline Trafo S P TV & 0.274 & 0.134 & -0.272 & -0.125 & 19 & 9.1 & 98.2 & 96.4 & 1.81 \\
\hline Trafo KW 37 & 0.128 & 0.026 & -0.125 & .0 .022 & 2.4 & 3.7 & 98.0 & 95.7 & 2.33 \\
\hline Trafo VSD 1 & 0.058 & 0.004 & -0.087 & -0.002 & 0.4 & 19 & 95.7 & 95.2 & 0.51 \\
\hline Cablo 4 & 0.436 & 0.017 & -0.432 & -0.016 & 4.6 & 0.9 & 99.4 & 98.4 & 1.05 \\
\hline Cablos & 0.187 & 0.013 & -0.187 & -0.013 & 0.3 & 0.1 & 98.4 & 98.2 & 0.14 \\
\hline Trafo 03b & 0.122 & 0.001 & -0.122 & 0.002 & 0.8 & 3.6 & 98.4 & 97.8 & 0.61 \\
\hline Trafo KW 03a & 0.122 & 0.001 & -0.122 & 0.002 & 0.8 & 3.6 & 98.4 & 97.8 & 0.61 \\
\hline Trafo KW PS & 0.187 & 0.013 & -0.185 & .0 .005 & 1.8 & 8.6 & 98.2 & 97.1 & 1.17 \\
\hline Cablat 6 & 0.043 & 0.020 & -0.037 & -0.018 & 5.5 & 1.4 & 97.1 & 85.6 & 11.49 \\
\hline Cablo? & 0.050 & 0.023 & -0.049 & -0.023 & 0.9 & 0.2 & 97.1 & 95.6 & 1.51 \\
\hline Cablos & 0.039 & 0.018 & .0 .036 & -0.018 & 2.3 & 0.6 & 97.1 & 919 & 5.19 \\
\hline Cabiag & 0.054 & 0.024 & .0 .050 & -0.023 & 3.6 & 0.9 & 97.1 & 91.1 & 598 \\
\hline Cablo 10 & 0.040 & 0.019 & -0.037 & -0.018 & 2.8 & 0.5 & 97.8 & 91.7 & 6.06 \\
\hline Cablo 12 & 0.043 & 0.022 & -0.042 & -0.021 & 1.7 & 0.7 & 97.8 & 94.1 & 3.66 \\
\hline Cablo 13 & 0.040 & 0.019 & -0.037 & -0.018 & 2.8 & 0.7 & 97.8 & 915 & 6.26 \\
\hline Cablo14 & 0.039 & 0.018 & -0.037 & -0.018 & 1.1 & 0.2 & 97.8 & 953 & 2.46 \\
\hline
\end{tabular}


Tabel 6. Bus Drop Pengujian tahap ke 2

\begin{tabular}{|c|c|c|c|c|}
\hline Bus ID & $\begin{array}{c}\text { Nominal } \\
\mathrm{kV}\end{array}$ & Voltage & MW Loading & \% Loading \\
\hline Bus1 & 0,4 & 99,99 & 2,701 & 0 \\
\hline Bus5 & 0,4 & 96,55 & 0,117 & 0 \\
\hline Bus9 & 0,4 & 95,71 & 0,125 & 0 \\
\hline Bus16 & 0,4 & 97,07 & 0,185 & 0 \\
\hline Bus19 & 1,1 & 95,2 & 0,087 & 0 \\
\hline Bus20 & 0,4 & 97,77 & 0,243 & 0 \\
\hline Bus28 & 0,4 & 95,11 & 0,032 & 0 \\
\hline Bus31 & 0,4 & 93,87 & 0,304 & 0 \\
\hline Bus39 & 6,3 & 92,7 & 0,538 & 0 \\
\hline Bus40 & 0,4 & 91,85 & 0,112 & 0 \\
\hline Bus41 & 0,4 & 91,77 & 0,151 & 0 \\
\hline Bus43 & 0,4 & 91,89 & 0,272 & 0 \\
\hline Bus48 & 0,4 & 96,93 & 0,318 & 0 \\
\hline Bus49 & 0,4 & 96,93 & 0,092 & 0 \\
\hline Bus50 & 0,4 & 96,93 & 0,136 & 0 \\
\hline Bus60 & 0,4 & 97,55 & 0,236 & 0 \\
\hline Bus61 & 0,4 & 97,55 & 0,197 & 0 \\
\hline Bus63 & 0,4 & 97,55 & 0,077 & 0 \\
\hline Bus70 & 0,4 & 96,36 & 0,272 & 0 \\
\hline Bus78 & 0,4 & 96,36 & 0,042 & 0 \\
\hline Bus79 & 0,4 & 96,36 & 0,144 & 0 \\
\hline Bus98 & 0,4 & 92,21 & 0,065 & 0 \\
\hline Bus99 & 0,4 & 92,81 & 0,05 & 0 \\
\hline & & & & \\
\hline
\end{tabular}

\section{KESIMPULAN}

Dari hasil analisis aliran beban singkat di KSO Pertamina EP-GEO Cepu Indonesia Distrik 1 Kawengan dengan menggunakan software ETAP Power Station 12.6 dapat diambil kesimpulannya sebagai berikut:

1. Simulasi yang dilakukan adalah ketika beban semua beroperasi $100 \%$, sedangkan beban yang berada dilapangan kapasitas elektro motor memang dibuat lebih besar daripada daya yang diperlukan oleh setiap sumur.

2. Ketika daya semua beroperasi $100 \%, 1$ pembangkit yang dioperasikan yaitu sebebsar $1450 \mathrm{kVA}$ tidak akan mampu menopang semua beban yang ada, perlu pengoperasian 3 pembangkit yaitu 2 pembangkit $1450 \mathrm{kVA}$ ditambah dengan generator emergency sebesar $500 \mathrm{kVA}$.
3. Pada bus 39 terjadi drop tegangan lebih dari $10 \%$, Evaluasi yang lebih perlu diberikan pada jaringan GD. Trafo Timur Jauh karena jarak bus paling ujung terletak jauh dari pembangkit. Evaluasi yang paling berpengaruh adalah pada kabel 17 dan kabel 24.

4. Pada simulasi pada tahap pertama terdapat losses daya aktif sebesar $331.7 \mathrm{~kW}$ dan losses daya reaktif sebesar $311.6 \mathrm{kVAr}$, dengan adanya evaluasi di beberapa komponen sampai tahap keempat diperoleh losses daya aktif sebesar $74.1 \mathrm{~kW}$ dan losses daya reaktif sebesar $144.8 \mathrm{kVAr}$.

\section{DAFTAR PUSTAKA}

Hedbien, "Studi Aliran Daya $115 \mathrm{kV}$ di PT. Chevron Pasific Indonesia", 22 Juni 2008, 
Http://one.indoskripsi.com/node/3585, 18 Juli 2009.

Hosea Emmy, Yusak Tanoto, "Perbandingan Analisa Aliran Daya dengan Menggunakan Metode Algoritma Genetika dan Metode Newton-Rhapson", Http://getcited.org/pub/103449905, 25 Juli 2009.

Marsudi, Djiteng 2005, Pembangkitan Energi Listrik, Erlangga, Jakarta.

Saadat,hadi 1999, Power System Analysis, The McGraw-Hill Companies, Singapore.
Stevenson Jr, W D 1994, 'Analisis Sistem Tenaga Listrik', edisi ke-4, PT. Gelora Aksara Pratama, Jakarta.

Sulistyarso, Edhy 2010, Analisis Aliran BebanSistem Ditribusi Menggunakan ETAP 4.0.0,. Universitas Muhammadiyah Surakarta.

Zuhal 1995, Dasar Teknik Tenaga Listrik dan Elektronika Daya, PT Gramedia Pustaka Utsama, Jakarta. 